\title{
Dynamic variations in the peripheral blood lymphocyte subgroups of patients with 2009 pandemic H1N1 swine-origin influenza A virus infection
}

Xichao Guo ${ }^{1 \dagger}$, Yu Chen ${ }^{1 \dagger}$, Xuefen $\mathrm{Li}^{2}$, Haishen Kong ${ }^{1}$, Shigui Yang ${ }^{1}$, Bo Ye ${ }^{2}$, Dawei Cui ${ }^{2}$, Wei Wu ${ }^{1}$ and Lanjuan $\mathrm{Li}^{\mathrm{i}^{*}}$

\begin{abstract}
Background: Novel Influenza A ( $\mathrm{H} 1 \mathrm{~N} 1)$ is an acute respiratory infectious disease. Animal experiments indicated that when $\mathrm{H} 1 \mathrm{~N} 1$ virus infected early hosts, it showed strong $\mathrm{CD} 4^{+}, \mathrm{CD}^{+}$, and $\mathrm{CD}^{+} \mathrm{CD} 25^{+} \mathrm{T}$ cell reactions. The aim of this study was to investigate the dynamic fluctuations of the peripheral blood lymphocyte subgroups in patients infected with H1N1 swine-origin influenza A virus (S-OIV).
\end{abstract}

Methods: The frequency of T cells, B cells, natural killer (NK) cells, and regulatory T cells (Treg) in 36 severe H1N1 and 40 moderate $\mathrm{H} 1 \mathrm{~N} 1$ patients were detected at different periods by flow cytometry. In parallel, serum cytokines were detected by enzyme-linked immunosorbent assay and C-reactive protein (CRP) was analyzed through an image-type automatic biochemical analyzer. In addition, 20 healthy volunteers, who were not infected with 2009 H1N1 virus, were selected as controls.

Results: The frequency of NK cells were decreased in all cases and CD $19^{+}$B cells were increased in severe cases than those of the controls. At 1-2d from onset, the frequency of $\mathrm{CD} 4^{+}$and $\mathrm{CD} 4^{+} \mathrm{CD} 25^{+} \mathrm{T}$ cells in moderate cases was higher than in the severe cases. Serum cytokines, specifically IL-2, IL-4, IL-6, IL-10, and IFN- $\gamma$ exhibited no significant change both in the moderate and the severe cases during the whole monitoring process. In the early stage of the disease, serum CRP levels in the severe and moderate groups were significantly higher than that in the control group.

Conclusions: Patients showed different lymphocyte subgroup distributions between mild and severe cases, which might affect the incidence and development of 2009 H1N1.

\section{Background}

The latest public data from the Chinese Ministry of Health showed 120,940 confirmed H1N1 cases and 659 deaths were reported from the Chinese mainland as of January 2, 2010. Data analysis suggests that patients with chronic diseases, obese patients, and pregnant women are more liable to develop severe H1N1 influenza. After initial infection by the virus, the host innate immune system, as a first line of defense, takes protective measures

\footnotetext{
* Correspondence: ljil@zju.edu.cn

+ Contributed equally

'State Key Laboratory for Diagnosis and Treatment of Infectious Diseases, First Affiliated Hospital, School of Medicine, Zhejiang University, Hangzhou, 310003, PR China

Full list of author information is available at the end of the article
}

earlier than the adaptive immune system to avoid further viral invasion or replication [1]. Animal experiments indicated that when the swine-origin influenza A virus (S-OIV) infected early hosts, it elicited strong $\mathrm{CD} 4^{+}$, $\mathrm{CD} 8^{+}$, and $\mathrm{CD} 4^{+} \mathrm{CD} 25^{+} \mathrm{T}$ cell reactions [2]. $\mathrm{CD} 4^{+}$and $\mathrm{CD}^{+} \mathrm{T}$ cells are related to viral immunity and the lack of these cells would lead to a delay in viral clearance and an increase in mortality [3-5]. On the other hand, $\mathrm{CD} 4{ }^{+} \mathrm{CD} 25^{+}$cells are $\mathrm{T}$ cell subsets with an immune inhibition function and could play an important regulatory role in a variety of infectious diseases [6-8]. These complex molecular and cellular mechanisms are helpful in controlling and eliminating the acute stage of viral infection. Although successfully eliminating the virus is
C Biomed Central

() 2011 Guo et al; licensee BioMed Central Ltd. This is an Open Access article distributed under the terms of the Creative Commons Attribution License (http://creativecommons.org/licenses/by/2.0), which permits unrestricted use, distribution, and reproduction in any medium, provided the original work is properly cited. 
essential, the response of virus-specific $\mathrm{T}$ cells to the hosts could also result in tissue damage and autoimmune responses. Therefore, monitoring the variation of cellular immune functions in $\mathrm{H} 1 \mathrm{~N} 1$ patients have important clinical significance. The aim of this study is to analyze the dynamic fluctuations of T cells, B cells, natural killer (NK) cells, and regulatory $\mathrm{T}$ cells in patients infected with novel influenza $\mathrm{H} 1 \mathrm{~N} 1$, as well as serum cytokines and C-reactive protein (CRP).

\section{Methods}

\section{Enrollment of study subjects}

Up to 76 H1N1 outpatients and inpatients were chosen from August to December 2009 in the Department of Infectious Diseases, First Affiliated Hospital, School of Medicine, Zhejiang University. Among these, 36 cases were severe and 40 cases were moderate (Table 1 ). In addition, 20 healthy volunteers who were not infected with $2009 \mathrm{H} 1 \mathrm{~N} 1$ virus, were selected as controls. There were no statistical differences between their ages and genders compared with the H1N1 patients.

The diagnostic criteria for H1N1 were based on the Influenza A H1N1 Flu Clinic Program (pilot version of the second edition, 2009) released by the Chinese Ministry of Health in July 2009. Its main content includes the following:
I. Confirmation standard of Influenza A (H1N1) cases: Patients are considered to have contracted the virus if they present with influenza-like clinical manifestations and had one or more of the following laboratory test results: (1) Positive for S-OIV nucleic acid (through real-time RT-PCR and RT-PCR); (2) S-OIV is isolated and attained; and (3) Specific neutralizing antibody titers for serum S-OIV are increased four times or more.

II. Severe cases: When confirmed or suspected cases manifest one of the following signs, they are considered as severe: (1) Complicated pneumonia with or without hypoxemia and respiratory failure; (2) toxic shock; and (3) multiple organ dysfunction syndrome or multiple organ failure.

The study protocol was approved by the Ethics Review Committee of the First Affiliated Hospital, School of Medicine, Zhejiang University. All subjects understood the procedures and consented participate in the study.

\section{Sample collection and analysis}

On day 1, 2, 3, 5, 7, 9, 11, 14, and 21, $2 \mathrm{~mL}$ of whole blood (EDTA-K2 anticoagulant) and $1.5 \mathrm{~mL}$ of serum were collected from H1N1 patients for the detection of lymphocyte subgroups, cytokines, and CRP. The same sample collection was carried out in the control group.

Table 1 Basic characteristic of patients with severe H1N1and moderate H1N1

\begin{tabular}{|c|c|c|c|}
\hline Variable & severe H1N1 $(n=36)$ & moderate H1N1 $(n=40)$ & $P$-value \\
\hline Age, mean $\pm S D$, years* & $40.1 \pm 18.6$ & $26.1 \pm 8.0$ & 0.006 \\
\hline Male/Female distribution, $N(\%){ }^{\wedge}$ & $20 / 25(55 \% / 45 \%)$ & 20/20(50\%/50\%) & 0.653 \\
\hline \multicolumn{4}{|l|}{ Prodromal symptoms, $N(\%) `$} \\
\hline Fever $(T>38.5)$ & 28(78) & $16(40)$ & 0.001 \\
\hline Cough & $26(72)$ & $28(70)$ & 1.000 \\
\hline Dyspnea & 13(36) & 0 & $<0.001$ \\
\hline Gastrointestinal & $4(11)$ & $3(7)$ & 0.702 \\
\hline Myalgia & $23(64)$ & $10(25)$ & 0.001 \\
\hline \multicolumn{4}{|l|}{ Co-morbidities, $N(\%)$} \\
\hline COPD & $12(33)$ & 0 & $<0.001$ \\
\hline Coronary artery disease & $4(11)$ & 0 & $<0.001$ \\
\hline Diabetes mellitus & $5(14)$ & 2(5) & 0.246 \\
\hline Hypertension & $5(14)$ & $2(5)$ & 0.246 \\
\hline Pregnancy & $4(11)$ & $1(2.5)$ & 0.131 \\
\hline Others (Hypothyroidism, Immunosuppression, Transplant) & 3(8) & 0 & 0.102 \\
\hline Changes in lung imaging examination, $N(\%)$ & $20(55)$ & $3(7)$ & $<0.001$ \\
\hline Patients using Oseltamivir, $N(\%)$ & $36(100)$ & $40(100)$ & 1.000 \\
\hline Oseltamivir treatment time, mean $\pm S D$, (days)* & $8.55 \pm 3.39$ & $3.60 \pm 1.00$ & $<0.001$ \\
\hline Patients using combined glucocorticoid, N (\%) ${ }^{\star}$ & 19(53) & 0 & $<0.001$ \\
\hline The number of people using the ventilato, $N(\%){ }^{\star}$ & $5(14)$ & 0 & $<0.001$ \\
\hline Average stay, mean $\pm S D$, days* & $13.71 \pm 4.77$ & $3.37 \pm 1.06$ & $<0.001$ \\
\hline Death toll, $N(\%)$ & $1(3)$ & 0 & 0.474 \\
\hline
\end{tabular}

Note: $\mathrm{SD}=$ standard deviation; $\mathrm{COPD}=$ chronic obstructive pulmonary disease. ${ }^{*}$ Date are reported as mean $\pm \mathrm{SD} ;{ }^{\wedge}$ Date are expressed as no. (\%). 
Afterwards, $100 \mu \mathrm{L}$ of anticoagulant was added into all flow tubes and $20 \mu \mathrm{L}$ of CD3-PC5, CD4-FITC, CD8-PE, CD3-FITC-CD(16+56)-PE, CD19-FITC, and CD25-PE mouse anti-human fluorescence monoclonal antibodies (BD Bioscience) was added. After mixing, the samples were incubated for $15 \mathrm{~min}$ away from light at room temperature. Red blood cell lysis and cell fixation using Coulter QPREP specimen processing instrument (Beckman Coulter Inc., USA) was conducted, and the cells more than $1 \times 10^{4}$ were counted through a flow cytometer (Coulter Cytomics FC 500, Beckman Coulter). The results were expressed as the percentages of CD4 ${ }^{+} \mathrm{CD} 25^{+}, \mathrm{CD}^{+}$, and $\mathrm{CD} 8^{+} \mathrm{T}$ cells, as well as those of $\mathrm{CD}_{19}{ }^{+} \mathrm{B}$ cells and $\mathrm{NK}$ (marked as $\mathrm{CD}^{-} \mathrm{CD} 16^{+} \mathrm{CD} 56^{+}$) cells found positive for the antigen marker in the total lymphocytes population. The data were collected and analyzed using the EXPO32 software (Beckman Coulter Inc., USA).

Serum CRP detection was conducted using the imagetype automatic biochemical analyzer (Beckman Coulter Inc., USA). The kit was also provided by the same company. Serum cytokines, namely IL-2, IL-4, IL-6, IL-10, and IFN- $\gamma$ were tested using an enzyme-linked immunosorbent assay (ELISA; Ex-cell). The experimental methods were in accordance with the instructions of the manufacturer in the reagent kit.

\section{Statistical analysis}

SPSS 13.0 statistical package was used for data processing. Measurement data were indicated as mean \pm standard deviation or percentages. Comparisons among groups were carried out using one-way ANOVA or $\chi^{2}$ test. Differences with $\mathrm{P}<0.05$ were considered statistically significant. Correlation analysis among the detection indicators were conducted using Spearman's rank correlation analysis.

\section{Results}

Demographic characteristics and clinical features of H1N1 Up to 76 patients with confirmed laboratory diagnoses of influenza were enrolled in this study. The baseline characteristics of the patients are summarized in Table 1 . The samples were predominantly composed of full-grown adults with S-OVI infection.

As shown in Table 1, the patients with severe H1N1 were significantly older than those that presented with moderate H1N1 (mean age, 40.1 years vs. 26.1 years; $\mathrm{P}<$ 0.01 ). The mean duration of symptoms before presentation was 4 days, with fever, cough, and myalgia as the most common in both groups. However, the patients with severe H1N1 had more prodromal symptoms (e.g., fever, dyspnea, and myalgia) and co-morbidities [e.g., chronic obstructive pulmonary disease (COPD) and coronary artery disease] than the patients with moderate H1N1 ( $\mathrm{p}$
0.01). Although a relationship with pregnancy was more common in the severe H1N1 group (four patients vs. one patient with moderate $\mathrm{H} 1 \mathrm{~N} 1$ ), this difference was not statistically significant (Table 1). Similarly, there was no difference in the other preexisting diseases such as diabetes mellitus and hypertension between the two groups.

Chest $\mathrm{x}$-rays were taken from all patients, and abnormalities were detected in 23 patients, 3 with moderate $\mathrm{H} 1 \mathrm{~N} 1$ and 20 with severe H1N1. Ten patients presented with radiological abnormalities attributable to chronic lung conditions without evidence of concurrent pneumonia.

Up to 15 patients with severe $\mathrm{H} 1 \mathrm{~N} 1$ were admitted to the intensive care unit (ICU) with preexisting diseases, such as COPD. All patients were treated with Oseltamivir (Tamiflu) and $53 \%$ of the severe $\mathrm{H} 1 \mathrm{~N} 1$ patients were additionally treated with glucocorticoids (19/36). The duration of Oseltamivir treatment was based on the Pandemic Influenza A (H1N1) 2009 Clinical Guidelines (Second Edition, 2009). However, the subjects were not given immunomodulators. Treatment response did not differ significantly between the two groups and the mean duration of hospital confinement was 13.7 days (range, 0-51 days) and 3.3 days (range, 0-11 days) for the severe and moderate patients, respectively. Overall, only one severe H1N1 patient died during the course of the study. No patient dropped out and all completed the 21-week follow-up.

\section{Peripheral blood lymphocyte subgroups changes}

The frequency of peripheral blood CD $19^{+}$B cell count of patients with severe $\mathrm{H} 1 \mathrm{~N} 1$ gradually increased within the first 3-14 d of treatment. The NK cell count showed a gradual decline, whereas the $\mathrm{T}$ cell subtypes $\left(\mathrm{CD} 4^{+} \mathrm{CD} 25^{+}\right.$, $\mathrm{CD}^{+}$, and $\mathrm{CD}^{+} \mathrm{T}$ cells) showed no significant changes. The frequency of peripheral $\mathrm{CD} 4{ }^{+} \mathrm{T}$ and $\mathrm{CD} 4{ }^{+} \mathrm{CD} 25^{+}$Treg cells of patients with moderate $\mathrm{H} 1 \mathrm{~N} 1$ were significantly higher than in patients with severe H1N1 within the first 1-2 d of treatment. The NK cell counts of patients with moderate $\mathrm{H} 1 \mathrm{~N} 1$ were similar to that of patients with severe $\mathrm{H} 1 \mathrm{~N} 1$, which demonstrated a gradual decline, whereas the frequency of $\mathrm{CD}_{19^{+}} \mathrm{B}$ and $\mathrm{CD} 8^{+} \mathrm{T}$ cells showed no significant changes.

The frequency of the different lymphocyte subsets at different periods were statistically compared and the results show that the frequency of peripheral $\mathrm{CD} 4^{+}$and $\mathrm{CD} 4{ }^{+} \mathrm{CD} 25^{+} \mathrm{T}$ cells in the moderate $\mathrm{H} 1 \mathrm{~N} 1$ patients were higher than that of the severe $\mathrm{H} 1 \mathrm{~N} 1$ patients within the first 1-2 d (Figures 1a and 1c; $\mathrm{P}<0.05$ ). The CD19 ${ }^{+} \mathrm{B}$ cell counts of the severe $\mathrm{H} 1 \mathrm{~N} 1$ patients were significantly higher than those of the moderate $\mathrm{H} 1 \mathrm{~N} 1$ patients and the control group for the same period (Figure 1e), whereas the NK cell counts were significantly less than that of the control group (Figure 1d; $\mathrm{P}<0.05$ ). The frequency of 


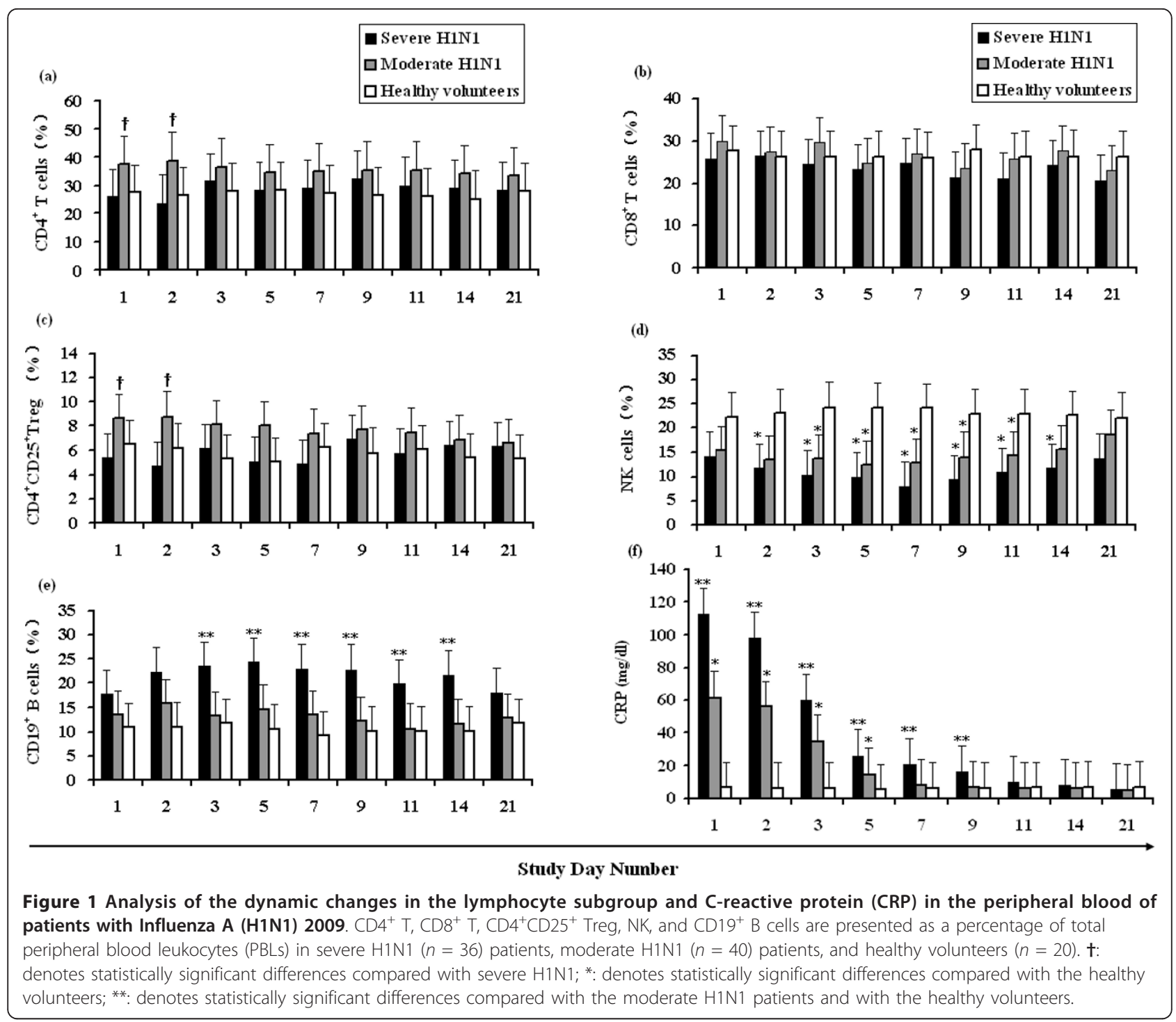

$\mathrm{CD}^{+} \mathrm{T}$ cells had no significant difference $(\mathrm{P}>0.05$; Figure 1b) among the three groups.

\section{Behavior of the serum CRP responses against a sustained treatment}

In the first 1-5 $\mathrm{d}$ of study, the serum CRP levels of both the patients with severe $\mathrm{H} 1 \mathrm{~N} 1$ and the patients with moderate $\mathrm{H} 1 \mathrm{~N} 1$ were significantly higher than that of the control group ( $\mathrm{P}<0.01$; Figure 1f). Correlation analysis of the $\mathrm{CD} 4^{+}, \mathrm{CD} 8^{+} \mathrm{T}, \mathrm{CD} 4{ }^{+} \mathrm{CD} 25^{+}, \mathrm{CD} 19^{+} \mathrm{B}$, and NK cells with CRP was conducted and the results indicate that the various lymphocyte subgroups had no significant correlations with CRP.

\section{Induction of serum cytokines activity}

The serum cytokines of patients, specifically IL-2, IL-4, IL-6, IL-10, and IFN- $\gamma$, whether the H1N1 infection was severe or moderate, showed no significant changes during the whole monitoring process (data not shown). The differences of the H1N1 patients with the control group had no statistical significance.

\section{Discussion}

Influenza $\mathrm{A}(\mathrm{H} 1 \mathrm{~N} 1)$ is the greatest pandemic threat in 2009 [9]. The clinical course of H1N1 can be severe, particularly for very young patients with complications. The immune response affected by pathological damage to the body caused by S-OVI and clinical prognosis. Studies have shown that the incidence of patients with severe H1N1 was highest in the 15- to 19 -year-old age group and the lowest for patients aged 65 or above [10]. Our clinical data also showed that the most severe infections occur in individuals younger than 25 years old or in middle-aged patients 
older than 55 years old with comorbidities, especially lung disease.

Based on local guidelines, antiviral treatment would be considered for severe or critical cases and high-risk patients infected with the influenza A pandemic (H1N1) virus within $48 \mathrm{~h}$ of onset. For patients who presented later than 2 days, the managing physicians were allowed to make decisions regarding antiviral use. Oseltamivir, given to patients older than 12 years, was prescribed according to the standard dosing regimen $(75 \mathrm{mg}$ twice daily orally, for 5 days). Dosage adjustment, whenever necessary, were based on the patient's renal function (75 $\mathrm{mg}$ daily, if creatinine clearance is $<30 \mathrm{~mL} / \mathrm{min}$ ). For children (1-12 years old), dosage adjustments were based on body weight (BW), that is: $30 \mathrm{mg}$ twice daily for children with BW $<15 \mathrm{~kg}$; $45 \mathrm{mg}$ twice daily for BW 15-23 kg; $60 \mathrm{mg}$ twice daily for BW $23-40 \mathrm{~kg}$; and $75 \mathrm{mg}$ twice daily for BW $>40 \mathrm{~kg}$. Accordingly, patients with acute respiratory distress syndrome (ARDS) were treated with high dose glucocorticoids over a short period of time, which has been proven beneficial and safe.

Several lines of experimental evidence suggest that H1N1 infections accompanied by a characteristic impairment of the innate immune response. By monitoring the host functional response, patients with increased risks of developing severe influenza-associated complications could be identified immediately $[11,12]$. The preliminary data from this study showed that the frequency of $\mathrm{CD} 19^{+} \mathrm{B}$ cells in patients with severe H1N1 was significantly higher than in the moderate and control groups (Figure 1e), and the frequency of NK cells in the severe and moderate groups were less than that of the control group. In the host innate immune system, NK cells are the major effector cells during acute infection, rapidly killing infected cells in the process. Previous studies have shown that the significant decrease in peripheral NK cell count is mainly because the S-OVI directly infected and killed NK cells, thereby limiting their activity and leading to their apoptosis in vivo [13].

Animal studies have found that $\mathrm{CD} 4^{+} \mathrm{T}, \mathrm{CD} 8^{+} \mathrm{T}$, and $\mathrm{CD} 19^{+} \mathrm{B}$ cells achieved peak values within 5-6 d after SOVI infection, whereas the $\mathrm{CD} 4{ }^{+} \mathrm{CD} 25^{+}$Treg cell count reached its peak at 24-48 h after infection [2]. Currently, the use of flow cytometric analysis to measure peripheral blood $\mathrm{CD} 4^{+}, \mathrm{CD} 8^{+}$, and $\mathrm{CD} 4^{+} \mathrm{CD} 25^{+} \mathrm{T}$ cells is a simple and common method. Reportedly, the mostly $\mathrm{CD} 4{ }^{+} \mathrm{CD} 25^{+} \mathrm{T}$ cells were also positive for FoxP3 [14]. In this experiment, the peak values for all lymphocyte subgroups in patients with severe H1N1 could not be detected. At least two mechanisms could account for the lower effector $\mathrm{T}$ cell response detected after the $\mathrm{S}$ OVI infection, and the peak response time for the effector $\mathrm{T}$ cells possibly missed. In addition, the virus could have also led to the immunotolerance of the $\mathrm{T}$ cells [15].

As intercellular signaling molecules, cytokines regulate the immune response, mediate inflammatory responses, and participate in tissue repair. Experiments have shown that only the peak values of IFN- $\alpha$ and IL- 6 could respectively be detected within 24 and $30 \mathrm{~h}$ in the serum of infected animals, as well as in the plasma of pediatric patients with severe influenza $[16,17]$. In this experiment, no statistically significant changes were found during the continuous monitoring of serum IL-2, IL-4, IL-6, IL-10, and IFN- $\gamma$ of patients with severe and moderate H1N1, as well as in the control group. This result might also be related to the immunotolerance of $\mathrm{T}$ cells, of which the peak detection might have been missed. The mechanisms responsible for maintaining these relatively constant levels remain unclear.

CRP is an acute phase protein produced by the liver and is a sensitive marker for the inflammatory response. It did not directly related to viral load [17]. However, CRP continuously increased in the initial stages of infection for both the patients with severe and those with moderate H1N1. The CRP of patients with severe H1N1 took longer to return to normal, which might be the result of underlying disease. Each lymphocyte subgroup has made correlatively analyzed with CRP and the results show no significant correlations.

In conclusion, S-OIV could stimulate the cellular immune response. When accompanied by $\mathrm{CD} 19^{+} \mathrm{B}$ cell increase and a continuous NK cell decline, it could indicate that the body is in a dynamic balance of the antiinfection immunity and autoimmune damage; this is particularly true for patients with severe influenza. Each lymphocyte subgroup in patients with $\mathrm{H} 1 \mathrm{~N} 1$ plays a more important antiviral role in the early stages of disease, but excessive immune response also leads to the increase and development of infection.

\section{Acknowledgements}

This study was supported by grants from the Major National Science and Technology Projects for Infectious Diseases (No. 2009ZX10602) and the National Natural Science Foundation of China (No. 81001271).

\section{Author details}

${ }^{1}$ State Key Laboratory for Diagnosis and Treatment of Infectious Diseases, First Affiliated Hospital, School of Medicine, Zhejiang University, Hangzhou, 310003, PR China. ²Department of Laboratory Medicines, First Affiliated Hospital, School of Medicine, Zhejiang University, Hangzhou, 310003, PR China.

\section{Authors' contributions}

$X G$ and $Y C$ performed the majority of experiments and drafted the manuscript. $X L$ and HK followed-up the patients and involved in editing the manuscript. SY and WW did most of clinical works. BY and DC provided analytical tools. LL was the principal investigator and provides all facilitates to complete this work. All authors read and approved the final manuscript. 


\section{Competing interests}

The authors declare that they have no competing interests.

Received: 30 November 2010 Accepted: 10 May 2011

Published: 10 May 2011

\section{References}

1. Koyama S, Ishii KJ, Coban C, Akira S: Innate immune response to viral infection. Cytokine 2008, 43:336-341.

2. Lange E, Kalthoff D, Blohm U, Teifke JP, Breithaupt A, Maresch C, Starick E, Fereidouni S, Hoffmann B, Mettenleiter TC, Beer M, Vahlenkamp TW: Pathogenesis and transmission of the novel swine-origin influenza virus A/H1N1 after experimental infection of pigs. J Gen Virol 2009, 90:2119-2123.

3. Mackenzie CD, Taylor PM, Askonas BA: Rapid recovery of lung histology correlates with clearance of influenza virus by specific CD8+ cytotoxic $T$ cells. Immunology 1989, 67:375-381.

4. Bender BS, Croghan T, Zhang L, Small PA Jr: Transgenic mice lacking class I major histocompatibility complex-restricted T cells have delayed viral clearance and increased mortality after influenza virus challenge. J Exp Med 1992, 175:1143-1145.

5. Eichelberger M, Allan W, Zijistra M, Jaenisch R, Doherty PC: Clearance of influenza virus respiratory infection in mice lacking class I majorhistocompatibility complex-restricted CD8 ${ }^{+}$T cells. J Exp Med 1991, 174:875-880.

6. Belkaid $Y$, Rouse BT: Natural regulatory $T$ cells in infectious disease. Nat Immunol 2005, 6:353-360.

7. Mills KH: Regulatory T cells: friend or foe in immunity to infection? Nat Rev Immunol 2004, 4:841-855.

8. Suvas S, Rouse BT: Treg control of antimicrobial T cell responses. Curr Opin Immunol 2006, 18:344-348.

9. World Health Organization: Influenza A ( $\mathrm{H} 1 \mathrm{~N} 1)$ : WHO announces pandemic alert phase 6, of moderate severity. 2009 [http://www.euro.who.int/ mediacentre/PR/2009/20090611_1], Copenhagen: WHO.

10. Cullen G, Martin J, O'Donnell J, Boland M, Canny M, Keane E, McNamara A, O'Hora A, Fitzgerald M, Jackson S, Igoe D, O'Flanagan D: Surveillance of the first 205 confirmed hospitalised cases of pandemic H1N1 influenza in Ireland, 28 April - 3 October 2009. Euro Surveill 2009, 14:19389.

11. Agrati C, Gioia C, Lalle E, Cimini E, Castilletti C, Armignacco O, Lauria FN, Ferraro F, Antonini M, Ippolito G, Capobianchi MR, Martini F: Association of profoundly impaired immune competence in $\mathrm{H} 1 \mathrm{~N} 1 \mathrm{v}$-infected patients with a severe or fatal clinical course. Infect Dis 2010, 202:681-689.

12. Giamarellos-Bourboulis EJ, Raftogiannis M, Antonopoulou A, Baziaka F, Koutoukas P, Savva A, Kanni T, Georgitsi M, Pistiki A, Tsaganos T, Pelekanos N, Athanassia S, Galani L, Giannitsioti E, Kavatha D, Kontopidou F, Mouktaroudi M, Poulakou G, Sakka V, Panagopoulos P, Papadopoulos A, Kanellakopoulou K, Giamarellou H: Effect of the novel influenza A (H1N1) virus in the human immune system. PLoS One 2009, 4:e8393.

13. Mao H, Tu W, Qin G, Law HK, Sia SF, Chan PL, Liu Y, Lam KT, Zheng J, Peiris M, Lau YL: Influenza virus directly infects human natural killer cells and induces cell apoptosis. J Virol 2009, 83:9215-9222.

14. Szodoray P, Papp G, Horvath IF, Barath S, Sipka S, Nakken B, Zeher M: Cells with regulatory function of the innate and adaptive immune system in primary Sjögren's syndrome. Clin Exp Immunol 2009, 157:343-349.

15. Wahl A, McCoy W, Schafer F, Bardet W, Buchli R, Fremont DH, Hildebrand WH: T-cell tolerance for variability in an HLA class I-presented influenza A virus epitope. J Virol 2009, 83:9206-9214.

16. Heltzer ML, Coffin SE, Maurer K, Bagashev A, Zhang Z, Orange JS, Sullivan KE: Immune dysregulation in severe influenza. J Leukoc Biol 2009, 85:1036-1043

17. Barbé $F$, Atanasova $K$, Van Reeth $K$ : Cytokines and acute phase proteins associated with acute swine influenza infection in pigs. Vet J 2011, 187:48-53.

doi:10.1186/1743-422X-8-215

Cite this article as: Guo et al:: Dynamic variations in the peripheral blood lymphocyte subgroups of patients with 2009 pandemic H1N1 swine-origin influenza A virus infection. Virology Journal 2011 8:215.

\section{Submit your next manuscript to BioMed Central and take full advantage of:}

- Convenient online submission

- Thorough peer review

- No space constraints or color figure charges

- Immediate publication on acceptance

- Inclusion in PubMed, CAS, Scopus and Google Scholar

- Research which is freely available for redistribution

Submit your manuscript at www.biomedcentral.com/submit 